ISSN: 2302-8556

E-Jurnal Akuntansi Universitas Udayana

Vol.25.1.Oktober (2018): 83-108

DOI: https://doi.org/10.24843/EJA.2018.v25.i01.p04

\title{
Reaksi Pasar Terhadap Reentry Perusahaan Pada Indeks Saham Syariah Indonesia
}

\author{
Siti Roviah ${ }^{1}$ \\ Dodik Ariyanto ${ }^{2}$ \\ ${ }^{1,}$ Fakultas Ekonomi dan Bisnis Universitas Udayana (Unud), Bali, Indonesia \\ email: sitiroviahak@gmail.com/telp: +62 83114610469 \\ ${ }^{2}$ Fakultas Ekonomi dan Bisnis Universitas Udayana (Unud), Bali, Indonesia
}

\begin{abstract}
ABSTRAK
Indeks diperlukan sebagai indikator pergerakan harga dari sekuritas. Jika suatu saham mampu memenuhi kriteria indeks tertentu, maka memberikan tanda bahwa perusahaan memiliki kinerja yang di isyaratkan. Sebaliknya, ketika saham dikeluarkan dari salah satu indeks, maka perusahaan kurang mendapatkan kepercayaan lagi dari investor tertentu. Salah satu indeks yang terdaftar di Bursa Efek Indonesia (BEI) adalah Indeks Saham Syariah Indonesia (ISSI). Perusahaan yang memasuki ISSI harus memenuhi kriteria ISSI yang diatur dalam arahan Dewan Syariah Nasional dan Peraturan Bapepam-LK Nomor IX.A.13 tentang Penerbitan Efek Syariah. Penelitian ini bertujuan untuk mengetahui reaksi pasar di sepanjang pengumuman komposisi indeks ISSI. Populasi dalam penelitian ini adalah perusahaan-perusahaan yang reentry di ISSI dari tahun 2011-2014. Perusahaan yang melakukan reentry selama periode pengamatan, sebanyak 72 perusahaan. Penelitian ini menggunakan event study dengan windows pengamatan 20 hari. Pengujian hipotesis menggunakan uji beda dua sampel berpasangan (paired sample t-test).Hasil pengujian hipotesis menunjukkan tidak terdapat perbedaan abnormal return yang signifikan sebelum dan sesudah peristiwa reentry.
\end{abstract}

Kata kunci: abnormal return, reaksi pasar, reentry

\begin{abstract}
An index is required as an indicator to observe the movement of the price of securities. When shares of a company announced entering specific index, it is considered a sign that the company deserves more confidence from investors. Abnormal return occurs due to abnormal transactions throughout the event period. Selection is based on the length of the event period the number of observations and avoid the confounding effect. This study aimed to determine the reaction of the market along announcement of changes in the composition of the index. If there are differences, the market reaction to changes in the composition can be categorized as an announcement containing the information. Events throughout the 21-day period with a sample of companies that reentry amounted to 72 companies and 78 events reentry. Hypothesis testing using two different test paired samples (paired sample t-test). Hypothesis testing results showed no significant difference in abnormal returns before and after events reentry.
\end{abstract}

Keywords: Abnormal return, market reaction, reentry 


\section{PENDAHULUAN}

Pasar modal merupakan pasar untuk berbagai instrumen keuangan (sekuritas) jangka panjang yang bisa diperjual-belikan oleh pemerintah, public authorities, maupun perusahaan swasta (Luhur, 2010). Transaksi jual-beli sekuritas dalam pasar modal tersebut dilakukan dengan cara mempertemukan dua pihak, yaitu pihak yang membutuhkan dana dengan pihak yang menyediakan dana (investor).

Pasar modal dikatakan efisien apabila harga dari surat-surat berharga mencerminkan nilai dari perusahaan secara akurat. Kecepatan reaksi harga saham terhadap suatu informasi menggambarkan pula tingkat efisiensi suatu pasar (Hartono, 2007:11). Fama (1970) dalam Hartono (2013:549) melalui konsep Efficient Market Hypothesis (EMH) menyatakan bahwa suatu pasar dikatakan efisien (dalam bentuk setengah kuat), jika harga saham secara cepat menggambarkan sepenuhnya seluruh informasi baru dan relevan yang tersedia.

Hartono (2013a:125 dan 2013b:135) menyatakan suatu indeks diperlukan sebagai sebuah indikator untuk mengamati pergerakan harga dari sekuritas-sekuritas. Saat saham suatu perusahaan memasuki indeks tertentu, hal ini menandakan perusahaan layak mendapatkan kepercayaan lebih dari investor. Hal ini sejalan dengan Selection Criteria Hypothesis yang memusatkan perhatiannya pada efek dari kriteria yang diisyaratkan untuk masuk ke dalam indeks tersebut. Efek yang muncul dari perubahan komposisi indeks merupakan efek dari komponen fundamental perusahaan. Ketika suatu saham mampu memenuhi kriteria indeks tertentu, maka perusahaan tersebut memberikan tanda bahwa perusahaan memiliki kinerja yang 
memuaskan (Duque dan Madeira, 2005). Begitu sebaliknya, ketika suatu saham keluar dari suatu indeks maka perusahaan tidak lagi layak mendapatkan kepercayaan dari investor (Oktaviana, dkk ,2011).

Salah satu indeks yang terdaftar di Bursa Efek Indonesia (BEI) adalah Indeks Saham Syariah Indonesia (ISSI). Pemilihan indeks ini didasarkan pada saat ini pasar modal syariah bukan lagi menjadi tren di kalangan negara muslim semata, perkembangan industri keuangan syariah yang mencapai 15 persen per tahun di seluruh dunia menjadikan negara-negara kapitalis dan liberal sekalipun tertarik membuka layanan pasar modal ini. ISSI diluncurkan pada tanggal 12 Mei 2011. Indeks ini berisi dengan saham-saham yang berada di Daftar Efek Syariah (DES) yang dikeluarkan sesuai regulasi Bapepam-LK No.II.K.1 setiap 6 bulannya di bulan Mei dan Nopember. Tanggal basis yang digunakan adalah Desember 2007 dengan nilai 100. Indeks ini dihitung sama dengan perhitungan Indeks Harga Saham Gabungan (IHSG) yaitu menggunakan cara rata-rata tertimbang kapitalisasi pasar (value weighted). Kapitalisasi pasar dari Indeks Saham Syariah Indonesia sampai saat ini sekitar 43,6 persen dari total keseluruhan kapitalisasi pasar. Bersesuain dengan Selection Criteria Hypothesis, maka untuk memasuki ISSI perusahaan harus memiliki kemampuan serta kemauan untuk memenuhi kriteria ISSI yang diatur dalam arahan Dewan SyariahNasional dan Peraturan Bapepam - LK Nomor IX.A.13 tentang Penerbitan Efek Syariah. 
ISSI dievaluasi setiap enam bulan, yakni di bulan Mei dan Nopember. Pada saat evaluasi tersebut akan terdapat perusahaan yang baru dimasukkan, dikeluarkan, maupun yang sudah dikeluarkan kemudian berhasil masuk kembali (reentry). Tantangan untuk perusahaan yang dikeluarkan dari suatu indeks adalah bagaimana perusahaan tersebut dapat masuk kembali (reentry) dalam indeks tersebut.Banyak perusahaan yang tidak mampu berintegrasi ke dalam indeks jika sudah pernah dikeluarkan. (Tolbert,2012). Reentry secara harfiah dapat diartikan masuk kembali ke dalam suatu kelompok karena sebelumnya telah dikeluarkan dalam suatu kelompok tersebut.Penelitian ini menekankan reentry kepada peristiwa masuknya kembali suatu emiten ke dalam ISSI.

Reentry erat kaitannya dengan perubahan komposisi indeks. Penelitian terdahulu mengenai reaksi pasar terhadap perubahan komposisi indeks telah banyak dilakukan. Elayan, Li, dan Pinfold (2000) dalam penelitiannya terhadap perubahan komposisi indeks NZSE-10 dan NZSE-40 di Selandia Baru pada tahun 1991 sampai 2000 menemukan hasil bahwa pengumuman tersebut berpengaruh terhadap abnormal return saham.

Studi peristiwa (event study) merupakan sebuah metode untuk meneliti reaksi pasar terhadap peristiwa yang dipublikasikan sebagai suatu pengumuman. Event study dapat dipakai sebagai alat uji kandungan dari suatu pengumuman serta dapat pula dijadikan alat uji efisiensi pasar bentuk setengah kuat (Woon:2014). Hartono (2009: 392), mengemukakan bahwa informasi yang dipublikasikan sebagai suatu 
ISSN: 2302-8556

E-Jurnal Akuntansi Universitas Udayana

Vol.25.1.Oktober (2018): 83-108

pengumuman akan memberikan signal bagi investor dalam pengambilan keputusan investasi.

Pada waktu informasi diumumkan dan semua pelaku pasar sudah menerima informasi tersebut, mula-mula pelaku pasar menginterpretasikan dan menganalisis informasi tersebut sebagai signal baik (good news) atau signal buruk (bad news). Pasar diharapkan akan memberikan reaksi pada waktu pengumuman tersebut dipublikasikan, apabila pengumuman tersebut bernilai positif. Reaksi pasar ditunjukkan dengan adanya perubahan harga dari sekuritas akibat dari pengumuman tersebut. Reaksi ini dapat diukur dengan menggunakan return abnormal. Jika sebuah pengumuman memiliki kandungan informasi, pengumuman tersebut akan memberikan return abnormal kepada pasar. Sebaliknya, bila tidak mengandung informasi pengumuman tidak menimbulkan return abnormal kepada pasar (Hartono, 2000:392-393).

Harris dan Gurel (1986) menguji dampak perubahan komposisi indeks S\&P 500 periode 1973-1983 terhadap volume perdagangan dan excess return (return abnormal). Penelitian ini menemukan bahwa terdapat return abnormal dan peningkatan volume perdagangan di sekitar tanggal pengumuman perubahan komposisi indeks. Bildik dan Gülay (2001) melakukan penelitian serupa terhadap pengumuman perubahan komposisi ISE-100 dan ISE-30 pada tahun 1995 sampai 
2000 di pasar modal Turki. Penelitian ini menunjukkan bahwa pengumuman tersebut berpengaruh secara signifikan pada return abnormal dan volume perdagangan saham.

Penelitian mengenai pengujian reaksi pasar salah satunya dapat diukur melalui adanya abnormal return di sekitar tanggal pengumuman reentry. Abnormal return berasal dari selisih return realisasi dan return ekspektasi. Return ekspektasi disebut juga dengan return normal (retun yang diharapkan investor). Perbedaan hasil penelitian mengenai perbedaan abnormal return di sekitar pengumuman menjadikan topik penelitian ini semakin menarik. Rahman (2007) meneliti reaksi pasar terhadap pengumuman perubahan komposisi Kuala Lumpur Sharia Index (KLSI) periode 1999-2005 menggunakan average abnormal return (AAR).Dengan menggunakan ujit, ditemukan bahwa pengumuman perubahan komposisi KLSI berpengaruh terhadap AAR.

Ha: Terdapat perbedaan abnormal return sebelum dan setelah peristiwa reentry perusahaan dalam Indeks Saham Syariah Indonesia (ISSI)

\section{METODE PENELITIAN}

Melakukan pengujian efisiensi pasar sering menggunakan informasi yang berasal dari luar emiten. Salah satu informasi yang berasal dari luar dan sering menghasilkan hasil yang membingungkan adalah perubahan komposisi indeks. Perubahan komposisi indeks memberikan sinyal positif bahwa perusahaan memiliki prospek positif di masa mendatang. Akan tetapi dalam perspektif yang berbeda, pengumuman ini tidak memberikan arus kas secara langsung bagi perusahaan sehingga dikategorikan sebagai aktivitas non ekonomi. 
ISSN: 2302-8556

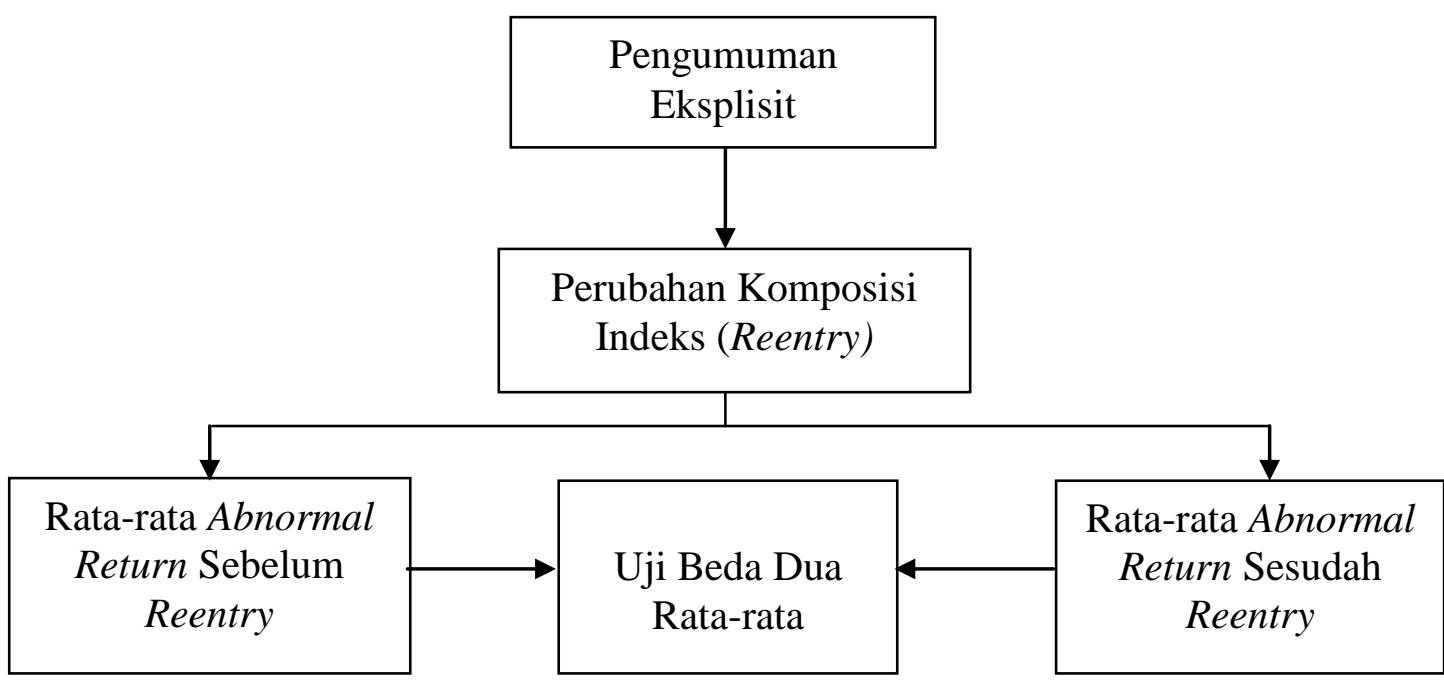

\section{Gambar 1. Kerangka Pemikiran Teoritis}

Abnormal return terjadi akibat terjadi selisih lebih ataupun kurang antara actual return maupun expected return. Perhitungan actual return diperoleh melalui harga saham sekarang dikurangi harga saham sebelumnya, sedangkan hasil expected return dihitung menggunakan market model. Perbedaan hasil penelitian mengenai perbedaan abnormal return yang terjadi sebelum dan sesudah pengumuman reentry menjadi topik yang menarik untuk diteliti. Hal ini disebabkan karena hasil dari penelitian akan menjadi acuan untuk melakukan keputusan investasi. Adanya abnormal return positif akan menimbulkan reaksi pasar yang positif sehingga investor berusaha mendapatkan keuntungan dari return positif yang didapat dari hasil transaksi. Adanya abnormal return negatif akan menyebabkan investor menarik dana yang sebelumnya disiapkan untuk diinvestasikan. 
Obyek penelitian adalah suatu sifat dari obyek yang ditetapkan oleh peneliti untuk dipelajari dan kemudian memperoleh kesimpulan (Sugiyono, 2010:38). Dari pengertian tersebut dapat dijelaskan bahwa obyek penelitian merupakan sumber dan tempat kita akan memperoleh data. Obyek dari penelitian ini adalah reaksi pasar terhadap perusahaan yang reentry dalam ISSI periode 2011-2014.

Ditinjau dari rumusan masalah dan hipotesis yang teah diuraikan, maka variabel yang akan dianalisis dalam penelitian ini adalah abnormal return . Variabel ini akan diamati selama periode jendela yaitu 21 hari termasuk hari h pengumuman. Hasil pengamatan selama 21 hari nanti akan didokumentasikan dan dilakukan pengujian atas reaksi pasar yang terjadi. Abnormal return merupakan selisih antara actual return (tingkat keuntungan yang sebenernya diperoleh) dan expected return (tingkat keuntungan yang diharapkan). Actual return dapat dihitung melalui selisih harga saham sekarang dan harga saham sebelumnya kemudian dibagi dengan harga saham sebelumnya.

Besarnya expected return saham dapat diukur dari berbagai metode dan dalam penelitian ini menggunakan market model. Alasan digunakannya model ini adalah karena model ini memberikan kemudahan dalam melakukan pendeteksian abnormal return dibanding model yang lainnya. Market model memiliki potensi untuk menghasilkan tes statistik yang kuat dibanding model statistik yang dihasilkan model lainnya yaitu mean adjusted dan market adjusted model (Hartono, 2010). Penelitian ini akan menggunakan event study untuk mengamati pergerakan abnormal return dari hari ke hari dengan periode jendela 20 hari. Pengumuman perubahan 
ISSN: 2302-8556

komposisi ISSI adalah $\mathrm{t}=0$. Periode jendela dibagi menjadi dua yaitu $\mathrm{t}=-10(10$ hari sebelum pengumuman perubahan komposisi indeks) dan $t=+10$ (10 hari setelah pengumuman perubahan komposisi indeks). Penentuan periode jendela didasarkan pada penelitian-penelitian sebelumnya, jenis peristiwa yang menyebabkan reaksi pasar terhadap sinyal yang diberikan sangat cepat dan disamping itu untuk menghindari adanya confounding effect atau tercampurnya informasi dari suatu peristiwa dengan peristiwa lain (Hartono, 2010).

Data kuantitatif, yaitu data yang dapat dinyatakan dalam bentuk angka, dan merupakan data yang berskala ukur interval dan rasio (Rahyuda dkk., 2004: 75). Data kuantitatif dalam penelitian ini adalah return perusahaan yang terdaftar di Bursa Efek Indonesia (BEI) dan terdaftar di ISSI periode 2011-2014. Data kualitatif, yaitu data yang sifatnya hanya menggolongkan saja dan tidak dapat diwujudkan dalam bentuk angka. Data kualitatif dalam penelitian ini adalah daftar nama perusahaan yang reentry dalam ISSI periode 2011-2014. Sumber data yang digunakan dalam penelitian ini merupakan data sekunder yaitu sumber data yang diperoleh peneliti secara tidak langsung melalui media perantara dan melalui kegiatan dokumentasi (diperoleh dan dicatat oleh pihak lain). Data sekunder berupa bukti, catatan atau laporan historis yang telah tersusun dalam arsip (data dokumenter) yang dipublikasi dan yang tidak dipublikasi (Indriantoro dan Supomo, 2009: 147).Data sekunder digunakan dengan alasan tidak memungkinkan bagi peneliti untuk memperolehnya secara langsung. 
Populasi adalah jumlah keseluruhan dari unit analisis yang ciri-cirinya akan diduga (Rahyuda dkk., 2004: 36). Populasi dalam penelitian ini adalah perusahaanperusahaan yang reentry dalam ISSI dari tahun 2011-2014. Sampel adalah bagian dari jumlah dan karakteristik yang dimiliki oleh populasi (Rahyuda dkk., 2004: 42). Pengambilan sampel berarti mengambil sebagian saja dari populasi untuk menggambarkan sifat populasi yang bersangkutan dan harus representatif. Teknik pengambilan sampel yang digunakan adalah non probability sampling yaitu teknik pengambilan sampel yang tidak memberi peluang atau kesempatan sama bagi setiap unsur atau anggota populasi untuk dipilih menjadi sampel (Sugiyono, 2009: 120). Bagian dari teknik non probability sampling yang digunakan dalam penelitian ini adalah metode purposive sampling, yaitu peneliti memiliki tujuan yang spesifik dalam memilih sampel secara tidak acak (Indriantoro dan Supomo, 2009: 131).

Tabel 1.

Jumlah Populasi dan Sampel

\begin{tabular}{cll}
\hline No. & Keterangan & Jumlah \\
\hline 1. & Populasi & 99 \\
2. & Tidak memenuhi kriteria Purposive Sampling pertama & 2 \\
3. $\quad$ Tidak memenuhi kriteria Purposive Sampling kedua & 19 \\
4. $\quad$ Sampel & 78 \\
\hline \multicolumn{2}{l}{ Sumber $:$ Data diolah, 2015 }
\end{tabular}

Dari 85 perusahaan yang melakukan reentry yang terdaftar di Indeks Saham Syariah Indonesia (ISSI) periode 2011-2014 sebanyak 72 perusahaan yang memenuhi kriteria purposive sampling untuk menjadi sampel dalam penelitian dan 78 peristiwa reentry. Perusahaan yang reentry tahun 2011 sebanyak 10 perusahaan, tahun 2012 
ISSN: 2302-8556

E-Jurnal Akuntansi Universitas Udayana

Vol.25.1.Oktober (2018): 83-108

sebanyak 22perusahaan, tahun 2013 sebanyak 31 perusahaan, dan tahun 2014 sebanyak 22 perusahaan.

Teknik analisis data yang digunakan untuk menguji hipotesis dalam penelitian ini adalah model analisis paired sample t-test dan analisis dalam penelitian ini menggunakan program software SPSS. Tahapan untuk melakukan pengujian dimulai dari menghitung actual return, expected return, return saham harian, kemudian melakukan regresi return saham harian dengan return pasar harian untuk memperoleh alpha dan beta saham. Selanjutnya, menghitung abnormal return masing-masing emiten sebelum dan setelah reentry.

Pengujian statistik $t$ test perlu dilakukan untuk mengetahui signifikansi keberadaan abnormal return. Langkah selanjutnya adalah melakukan pengujian hipotesis untuk variabel penelitian dengan menggunakan uji analisis pairedsample ttest. Untuk tingkat signifikansi atau nilai alpha $(\alpha)$ yang umum dipakai dalam penelitian sosial adalah 0,05. Dalam penelitian ini ditetapkan tingkat signifikansi untuk menolak $\mathrm{H}_{0}$ adalah sebesar 0,05 atau 5 persen. Uji analisis pairedsample t-test sering digunakan untuk menguji model analisis data sebelum-sesudah. Uji analisis ini digunakan karena sampel perusahaan yang melakukan reentry pada periode 20112014. Uji beda digunakan untuk menilai perlakuan tertentu pada satu sampel yang sama pada dua periode yang tidak bersamaan. Pengamatan yang dimaksud dalam penelitian ini adalah pengumuman perubahan komposisi indeks. 
Return tidak normal merupakan selisih antara return sesungguhnya dan return yang diharapkan oleh investor. Untuk mendapatkan hal tersebut, dilakukan perhitungan dengan tujuh tahapan sebagai berikut:

Menghitung actual return (Hartono, 2010:207):

$$
R_{i t}=\frac{P_{i t}-P_{i t-1}}{P_{i t-1}}+\text { Yield. }
$$

Notasi:

$R_{i t} \quad=$ Return sesungguhnya yang terjadi untuk sekuritas ke-i pada periode peristiwa ke-t.

$P_{i t} \quad=$ Harga sekarang relatif

$P_{i t-1} \quad=$ Harga sebelumnya

Menghitung return pasar harian (Hartono, 2010: 207):

$$
\mathrm{R}_{m t}=\frac{I H S G_{t}-I H S G_{t-1}}{I H S G_{t-1}}
$$

Notasi:

$\mathrm{R}_{\mathrm{mt}} \quad=$ Return pasar pada waktu ke-t.

$\mathrm{IHSG}_{\mathrm{t}}=$ Indeks Harga Saham Gabungan hari ke-t

Meregresikan return pasar harian dengan actual return untuk mendapatkan alpha dan beta, perhitungan ini sebelumnya digunakan juga oleh Ayu Mila (2010) :

$$
\beta=\frac{n(\Sigma X Y)-(\Sigma X)(\Sigma Y)}{n\left(\Sigma X^{2}\right)-(\Sigma X)^{2}} \quad \alpha=\frac{\Sigma Y-\beta(\Sigma X)}{n}
$$

Notasi:

$\mathrm{Y}=$ Return saham harian yang sesungguhnya atau $\mathrm{R}_{i t}$.

$\mathrm{X} \quad=$ Return pasar $(\mathrm{Rmt})$

$\mathrm{n} \quad=$ Periode Pengamatan 
ISSN: 2302-8556

E-Jurnal Akuntansi Universitas Udayana

Vol.25.1.Oktober (2018): 83-108

Menghitung expected return dengan menggunakan market model dilakukan dengan dua tahap (Tandelilin, 2010:574), yaitu membentuk model ekspektasi dengan data realisasi selama periode estimasi dan menggunakan model ekspektasi ini untuk mengestimasi return ekspektasi di periode jendela. Model ekspektasi menggunakan teknik regresi OLS (Ordinary Least Square) sebagai berikut:

$$
\mathrm{Rij}=\alpha \mathrm{i}+\beta \mathrm{iRMj}+\mathrm{Eij}
$$

Notasi:

$\mathrm{R}_{\mathrm{ij}} \quad=$ Return realisasi sekuritas ke-i pada periode estimasi ke-j

$\alpha_{\mathrm{i}} \quad=$ Intercept untuk sekuritas ke-i

$\beta_{\mathrm{i}} \quad=$ Koefisien slope yang merupakan beta sekuritas ke-i

$\mathrm{RM}_{\mathrm{j}} \quad=$ Return indeks pasar pada periode estimasi ke-j

$\mathrm{E}_{\mathrm{ij}} \quad=$ Kesalahan residu ke-i pada periode estimasi ke-j

$\mathrm{IHSG}_{\mathrm{t}-1} \quad=$ Indeks Harga Saham Gabungan hari ke- $\mathrm{t}-1$

Perhitungan abnormal return untuk masing-masing emiten (Hartono, 2010:580):

$$
\mathrm{AR}_{\mathrm{it}}=\mathrm{R}_{\mathrm{it}}-\mathrm{E}_{\mathrm{Rt}} \text {. }
$$

Notasi:

$$
\begin{array}{ll}
\mathrm{AR}_{\mathrm{it}} & =\text { Abnormal Return } \\
\mathrm{R}_{\mathrm{it}} & =\text { Actual Return } \\
\mathrm{E}_{\mathrm{Rt}} & =\text { Expected Return }
\end{array}
$$

Menghitung rata-rata abnormal return dirumuskan sebagai berikut(Hartono, 2010:592):

$$
\overline{\mathrm{AR} i t}=\frac{\sum_{i=1}^{n} A R_{i t}}{n}
$$

Notasi:

ARit = Rata-rata abnormal return 
$\mathrm{n} \quad=$ Sampel

ARit = Abnormal return

Uji normalitas berguna untuk menentukan data yang telah dikumpulkan berdistribusi normal atau diambil dari populasi normal. Berdasarkan beberapa penelitian empiris, data yang berjumlah lebih dari 30 angka (n > 30), dapat diasumsikan data berdistribusi normal. Untuk memberikan kepastian data yang dimiliki berdistribusi normal atau tidak, digunakan uji statistik normalitas. Data yang lebih dari 30 belum tentu berdistribusi normal, demikian sebaliknya data yang berjumlah kurang dari 30 belum tentu tidak berdistribusi normal, untuk itu perlu dilakukan pengujian. Uji statistik normalitas yang digunakan adalah Kolmogorov Smirnov. Kriteria yang digunakan dalam tes ini adalah dengan membandingkan antara tingkat signifikansi yang didapat dengan tingkat alpha yang digunakan, data tersebut dikatakan berdistribusi normal bila sig >alpha (Ghozali, 2006: 115).

Uji statistik non-parametrik adalah uji yang modelnya tidak menetapkan syarat-syarat mengenai parameter-parameter populasi. Uji non parametrik yang digunakan dalam penelitian ini adalah uji Willcoxon. Uji ini paling sering digunakan oleh peneliti ketika ingin menghindari asumsi-asumsi dari statistik uji-t (misalnya data sampel mengikuti distribusi normal) Wahid Sulaiman (2002: 79). Pengambilan keputusan didasarkan perbandingan antara nilai Asymp. Sig. dengan tingkat signifikansi $($ alpha $=0,05)$ yang digunakan dalam penelitian ini. Perbandingan tersebut adalah jika : Asymp. Sig. (2-tailed) $<0,05$ maka $\mathrm{H}_{0}$ ditolak. Jika : Asymp. Sig. (2-tailed $) \geq 0,05$ maka $\mathrm{H}_{0}$ diterima. 
Uji t sampel berpasangan merupakan uji parametrik yang digunakan untuk menguji hipotesis sama atau tidak berbeda $\left(\mathrm{H}_{0}\right)$ antara dua variabel. Data berasal dari dua pengukuran atau dua periode pengamatan yang berbeda yang diambil dari subjek yang dipasangkan. Langkah-langkah pengujian uji $t$ untuk pengujian sampel berpasangan sebagai berikut :

Menghitung selisih (d) antara pengamatan sebelum dan setelah. Menghitung total d $\left(\sum \mathrm{d}\right)$, lalu mencari mean d yaitu $\frac{\sum d}{n}$

Menghitung $\mathrm{d}-(\mathrm{d}$ rata rata), kemudian mengkuadratkan selisih tersebut dan menghitung total selisih kuadrat. Mencari deviasi standar $\left(\mathrm{Sd}^{2}\right)$ dengan rumus sebagai berikut:

$$
\mathrm{Sd}=\left(\frac{1}{n-1}\right) \times[\text { Total } \mathrm{d}-(\mathrm{d} \text { rata-rata })]
$$

Menghitung t hitung dengan rumus

$$
\mathrm{t}=\frac{X 1-X 2}{S d / \sqrt{n}}
$$

Notasi :

(X1-X2) : Rata-rata hitung pengamatan atau sampel untuk X1 pengamatan sebelum dan X2 pengamatan sesudah.

Sd : Deviasi standar sampel

n : Jumlah pengamatan sampel 
Pengambilan keputusan didasarkan perbandingan antara nilai Asymp. Sig. dengan tingkat signifikansi $($ alpha $=0,05)$ yang digunakan dalam penelitian ini. Perbandingan tersebut adalah jika : Asymp. Sig. (2-tailed) $<0,05$ maka $\mathrm{H}_{0}$ ditolak. Jika : Asymp. Sig. (2-tailed) $\geq 0,05$ maka $\mathrm{H}_{0}$ diterima.

\section{HASIL DAN PEMBAHASAN}

Pengujian deskriptif dilakukan untuk mengetahui gambaran umum tentang sampel. Deskripsi sampel berupa nilai tertinggi, nilai terendah, deviasi standar, dan rata-rata. Hasil analisis deskriptif dapat dilihat pada Tabel 2. Tabel 2 menjelaskan bahwa nilai abnormal return terendah pada H-10 sebesar -0,1009 yang dimiliki oleh Saranacentra Bajatama Tbk. Nilai abnormal return tertinggi dicapai oleh Tanah Laut Tbk. yaitu sebesar 0,3166 dan nilai rata-rata dari H-10 sebesar 0,031152. Deviasi standar pada H-10 sebesar 0,0563283.Pada H-9 nilai abnormal return terendah sebesar -0,1161 dan nilai abnormal return tertinggi sebesar 0,0954 yang masing-masing diperoleh oleh Plaza Realty Indonesia Tbk. dan Sunson Textile Manufacture Tbk. Nilai rata-rata dan deviasi standar pada H-9 sebesar 0,018598 dan 0,0384218.

Nilai abnormal return terendah pada H-8 sebesar -0,1379 dan nilai abnormal return tertinggi sebesar 0,1847 yang dicapai oleh Saranacentra Bajatama Tbk. dan Sugih Energy Tbk. Nilai rata-rata dan deviasi standar masing-masing sebesar 0,028882 dan 0,0464685. Pada H-7 nilai abnormal return terendah didapat oleh Bukit Darmo Property Tbk. sebesar $-0,1476$ dan nilai abnormal return tertinggi diperoleh 
ISSN: 2302-8556

E-Jurnal Akuntansi Universitas Udayana

Vol.25.1.Oktober (2018): 83-108

oleh Sunson Textile Manufacture Tbk. sebesar 0,4488. Nilai rata-rata abnormal return pada H-7 adalah sebesar 0,026369 dan deviasi standar sebesar 0,0676927.

Tabel 2.

Hasil Analisis Deskriptif

\begin{tabular}{|c|c|c|c|c|c|}
\hline & $\mathbf{N}$ & Minimum & Maximum & Mean & $\begin{array}{c}\text { Std. } \\
\text { Deviation }\end{array}$ \\
\hline Minsepuluh & 78 & -.1009 & .3166 & .031152 & .0563283 \\
\hline Minsembilan & 78 & -.1161 & .0954 & .018598 & .0384218 \\
\hline Mindelapan & 78 & -.1379 & .1847 & .028882 & .0464685 \\
\hline Mintujuh & 78 & -.1476 & .4488 & .026369 & .0676927 \\
\hline Minenam & 78 & -.0785 & .2153 & .020388 & .0442086 \\
\hline Minlima & 78 & -.1030 & .1312 & .019019 & .0358698 \\
\hline Minempat & 78 & -.1127 & .1401 & .017908 & .0351242 \\
\hline Mintiga & 78 & -.0809 & .3273 & .024564 & .0514155 \\
\hline Mindua & 78 & -.1044 & .1823 & .022460 & .0413963 \\
\hline Minsatu & 78 & -.0996 & .1385 & .020679 & .0340571 \\
\hline Event & 78 & -.1222 & .1576 & .023565 & .0391458 \\
\hline Plussatu & 78 & -.1399 & .3040 & .025566 & .0574168 \\
\hline Plusdua & 78 & -.1073 & .2999 & .027435 & .0520736 \\
\hline Plustiga & 78 & -.0662 & .3036 & .026180 & .0608804 \\
\hline Plusempat & 78 & -.1104 & .1943 & .025778 & .0461577 \\
\hline Pluslima & 78 & -.1146 & .2076 & .021228 & .0399369 \\
\hline Plusenam & 78 & -.1060 & .1147 & .024906 & .0337000 \\
\hline Plustujuh & 78 & -.1149 & .1177 & .020596 & .0364894 \\
\hline Plusdelapan & 78 & -.0601 & .1615 & .024296 & .0375572 \\
\hline Plussembilan & 78 & -.0672 & .1833 & .016354 & .0419987 \\
\hline Plussepuluh & 78 & -.1966 & .2013 & .019092 & .0502543 \\
\hline Valid N (listwise) & & & & & \\
\hline
\end{tabular}

Pada H-6 nilai abnormal return terendah didapat oleh Saranacentra Bajatama

Tbk. sebesar -0,0785 dan nilai abnormal return tertinggi diperoleh oleh Tanah Laut

Tbk. sebesar 0,2153. Nilai rata-rata abnormal return pada H-6 adalah sebesar 0,020388 dan deviasi standar sebesar 0,0442086.Pada H-5 nilai abnormal return terendah didapat oleh Saranacentra Bajatama Tbk. sebesar -0,1030 dan nilai 
abnormal return tertinggi diperoleh oleh Pembangunan Graha Lestari Indah Tbk. sebesar 0,1312. Nilai rata-rata abnormal return pada H-5 adalah sebesar 0,019019 dan deviasi standar sebesar 0,0358698.

Pada H-4 nilai abnormal return terendah sebesar -0,1127 dan nilai abnormal return tertinggi sebesar 0,1401 yang masing-masing diperoleh oleh Saranacentra Bajatama Tbk. dan Samindo Resources Tbk. Nilai rata-rata dan deviasi standar pada H-4 sebesar 0,017908 dan 0,0351242. Nilai abnormal return terendah pada H-3 sebesar -0,0809 dan nilai abnormal return tertinggi sebesar 0,3273 yang dicapai oleh Saranacentra Bajatama Tbk. dan Star Pacific Tbk. Nilai rata-rata dan deviasi standar masing-masing sebesar 0,024564 dan 0,0514155 .

Pada H-2 nilai abnormal return terendah didapat oleh Saranacentra Bajatama Tbk. sebesar -0,1044 dan nilai abnormal return tertinggi diperoleh oleh Star Pacific Tbk. sebesar 0,1823. Nilai rata-rata abnormal return pada H-2 adalah sebesar 0,022460 dan deviasi standar sebesar 0,0413963.Pada H-1 nilai abnormal return terendah didapat oleh Saranacentra Bajatama Tbk. sebesar -0,0996 dan nilai abnormal return tertinggi diperoleh oleh Pembangunan Graha Lestari Indah Tbk. sebesar 0,1385. Nilai rata-rata abnormal return pada H-1 adalah sebesar 0,020679 dan deviasi standar sebesar 0,0340571.

Pada hari $\mathrm{H}$ nilai abnormal return terendah didapat oleh Saranacentra Bajatama Tbk. sebesar -0,1222 dan nilai abnormal return tertinggi diperoleh oleh Bakrie Telecom Tbk. sebesar 0,1576. Nilai rata-rata abnormal return pada hari $\mathrm{H}$ adalah sebesar 0,023565 dan deviasi standar sebesar 0,0391458.Pada $\mathrm{H}+1$ nilai 
ISSN: 2302-8556

E-Jurnal Akuntansi Universitas Udayana

Vol.25.1.Oktober (2018): 83-108

abnormal return terendah sebesar -0,1399 dan nilai abnormal return tertinggi sebesar 0,3040 yang masing-masing diperoleh oleh Saranacentra Bajatama Tbk. dan Humpuss Intermoda Transportasi Tbk. Nilai rata-rata dan deviasi standar pada $\mathrm{H}+1$ sebesar 0,025566 dan 0,0574168 .

Nilai abnormal return terendah pada $\mathrm{H}+2$ sebesar -0,1073 dan nilai abnormal return tertinggi sebesar 0,2999 yang dicapai oleh Saranacentra Bajatama Tbk. dan Humpuss Intermoda Transportasi Tbk. Nilai rata-rata dan deviasi standar masingmasing sebesar 0,027435 dan 0,0520736.Pada $\mathrm{H}+3$ nilai abnormal return terendah didapat oleh Suryamas Duta Makmur Tbk. sebesar -0,0662 dan nilai abnormal return tertinggi diperoleh oleh Humpuss Intermoda Transportasi Tbk. Sebesar 0,3036. Nilai rata-rata abnormal return pada $\mathrm{H}+3$ adalah sebesar 0,026180 dan deviasi standar sebesar 0,0608804 .

Pada $\mathrm{H}+4$ nilai abnormal return terendah didapat oleh Bukit Darmo Property Tbk. sebesar -0,1104 dan nilai abnormal return tertinggi diperoleh oleh Humpuss Intermoda Transportasi Tbk. sebesar 0,1943. Nilai rata-rata abnormal return pada $\mathrm{H}+4$ adalah sebesar 0,025778 dan deviasi standar sebesar 0,0461577.Pada $\mathrm{H}+5$ nilai abnormal return terendah didapat oleh Saranacentra Bajatama Tbk. sebesar -0,1146 dan nilai abnormal return tertinggi diperoleh oleh Pudjiadi \& Sons Tbk. sebesar 0,2076. Nilai rata-rata abnormal return pada $\mathrm{H}+5$ adalah sebesar 0,021228 dan deviasi standar sebesar 0,0399369.Pada H+6 nilai abnormal return terendah sebesar - 
0,1060 dan nilai abnormal return tertinggi sebesar 0,1147 yang masing-masing diperoleh oleh Saranacentra Bajatama Tbk. dan Sunson Textile Manufacture Tbk. Nilai rata-rata dan deviasi standar pada H+6 sebesar 0,024906 dan 0,0337000.

Nilai abnormal return terendah pada $\mathrm{H}+7$ sebesar $-0,1149$ dan nilai abnormal return tertinggi sebesar 0,1177 yang dicapai oleh Saranacentra Bajatama Tbk. dan Sunson Textile Manufacture Tbk. Nilai rata-rata dan deviasi standar masing-masing sebesar 0,020596 dan 0,0364894.Pada H+8 nilai abnormal return terendah didapat oleh Bukit Darmo Property Tbk. sebesar -0,0601 dan nilai abnormal return tertinggi diperoleh oleh Ristia Bintang Mahkotasejati Tbk. sebesar 0,1615. Nilai rata-rata abnormal return pada $\mathrm{H}+8$ adalah sebesar 0,024296 dan deviasi standar sebesar 0,0375572 .

Pada H+9 nilai abnormal return terendah didapat oleh Jakarta International Hotels \& Development Tbk. sebesar -0,0672 dan nilai abnormal return tertinggi diperoleh oleh Indonesia Transport \& Infrastruktur Tbk. sebesar 0,1833. Nilai ratarata abnormal return pada $\mathrm{H}+9$ adalah sebesar 0,016354 dan deviasi standar sebesar 0,0419987. Pada H+10 nilai abnormal return terendah didapat oleh Saranacentra Bajatama Tbk. sebesar -0,1966 dan nilai abnormal return tertinggi diperoleh oleh Star Pacific Tbk. sebesar 0,2013. Nilai rata-rata abnormal return pada $\mathrm{H}+10$ adalah sebesar 0,019092 dan deviasi standar sebesar 0,0502543.

Nilai rata-rata abnormal return terkecil berada pada $\mathrm{H}+10$ dan bernilai negatif. Rata-rata abnormal return yang bernilai negatif berarti rata-rata return 
ISSN: 2302-8556

realisasi lebih kecil dibandingkan rata-rata return ekspektasi. Hal ini berarti return yang diperoleh oleh investor lebih rendah dari return yang diharapkan investor. Sedangkan rata-rata abnormal return positif tertinggi berada pada $\mathrm{H}-7$ dan rata-rata abnormal return positif didapatkan secara konsisten dari $\mathrm{H}-10$ hingga $\mathrm{H}+10$. Ratarata abnormal return postif berarti rata-rata return realisasi lebih tinggi dibandingkan dengan rata-rata return ekspektasi dan juga berarti investor mendapatkan return yang lebih besar dibandingkan return yang diharapkan.

Hipotesis yang akan diuji dalam penelitian ini adalah untuk mengetahui apakah terdapat perbedaan abnormal return sebelum dan sesudah pengumuman reentry di sepanjang periode peristiwa. Sebelum melakukan pengujian hipotesis, pengujian normalitas dilakukan terlebih dahulu untuk mengetahui data berdistribusi normal atau tidak. Normalitas data menentukan alat uji statistik yang digunakan dalam melakukan pengujian hipotesis.

Tabel 3 . Hasil Uji Normalitas Abnormal Return Sebelum dan Sesudah Reentry

\begin{tabular}{|c|c|c|c|}
\hline & & Sebelum & Setelah \\
\hline$\overline{\mathrm{R}}$ & & $\overline{78}$ & $\overline{78}$ \\
\hline \multirow{2}{*}{ Normal Parameters } & Mean & .023002 & .023143 \\
\hline & Std. Deviation & .0306979 & .0299327 \\
\hline Most Extreme & Absolute & .138 & .149 \\
\hline \multirow[t]{2}{*}{ Difference } & Positive & .093 & .140 \\
\hline & Negative & -.138 & 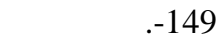 \\
\hline Kolmogorov-Smirnov & & 1.219 & 1.315 \\
\hline Asymp. Sig. (2-tailed) & & .102 & .063 \\
\hline
\end{tabular}


Tabel 3 menampilkan hasil uji normalitas rata-rata abnormal return sebelum dan sesudah dari 78 peristiwa menggunakan Kolmogorov-Smirnov Test. Hasil pengujian menunjukkan Sig. >alpha atau 0.063>0.05 sehingga dapat ditarik kesimpulan bahwa data terdistribusi normal. Data yang terdistribusi normal harus menggunakan uji parametrik yaitu Paired Sample t-test.

Tabel 4.

Hasil Uji Paired Sample Statistic Terhadap Perbedaan Abnormal Return

\begin{tabular}{|c|c|c|c|c|c|}
\hline & & Mean & $\mathbf{N}$ & Std. Deviation & Std. Error Mean \\
\hline Pair & $\mathrm{Seb}$ & 0,023002 & 78 & 0,0306979 & 0,0034759 \\
\hline 1 & Setelah & 0,023143 & 78 & 0,0299327 & 0,0033892 \\
\hline
\end{tabular}

Sumber: Data diolah, 2015

Tabel 5.

Hasil Uji Paired Sample Correlation Terhadap Perbedaan Abnormal Return

\begin{tabular}{lcccr}
\hline & N & & Correlation & Sig. \\
\hline Pair Sebelum \& Setelah & & 78 & .864 & .000 \\
\hline Sumber: Data diolah, 2015 & & & &
\end{tabular}

Tabel 6.

Hasil Uji Paired Sample T-Test Terhadap Perbedaan Abnormal Return

\begin{tabular}{|c|c|c|c|c|c|c|c|c|}
\hline & \multicolumn{5}{|c|}{ Paired Differences } & \multirow[b]{3}{*}{$\mathrm{t}$} & \multirow[b]{3}{*}{$\mathrm{df}$} & \multirow{3}{*}{$\begin{array}{l}\text { Sig. (2 } \\
\text { tailed) }\end{array}$} \\
\hline & \multirow[b]{2}{*}{ Mean } & \multirow{2}{*}{$\begin{array}{c}\text { Std. } \\
\text { Deviation }\end{array}$} & \multirow{2}{*}{$\begin{array}{c}\text { Std. Error } \\
\text { Mean }\end{array}$} & \multicolumn{2}{|c|}{$\begin{array}{l}95 \% \text { Confidence } \\
\text { Internal of the } \\
\text { Difference }\end{array}$} & & & \\
\hline & & & & Lower & Upper & & & \\
\hline $\begin{array}{l}\text { Pair1 } \\
\text { Sebelum - } \\
\text { Setelah }\end{array}$ & -.0001409 & .0158252 & .0017918 & -.003708 & .002427 & & & \\
\hline
\end{tabular}

Hasil uji Paired Sampleabnormal return sebelum dan sesudah menunjukkan bahwa rata-rata abnormal return sebelum reentry adalah 0,023002 dengan standar deviasi 0,0306979 dan rata-rata abnormal return setelah reentry sebesar 0,023143 dengan standar deviasi 0,0033892. Pada output Paired Sample Correlations 
menunjukkan korelasi sebesar 0,864 dengan signifikansi $0,000<0,05$, ini berarti korelasi sebelum dan setelah reentry berhubungan secara nyata. Output Paired Sample t-test menunjukkan sig.(2-tailed) > alpha (0.938>0.05) hal ini berarti H0 diterima. Hal ini berarti tidak terdapat perbedaan abnormal return sebelum dan setelah reentry. Hasil pengujian ini juga didukung oleh beberapa penelitian sebelumnya seperti Dita Roosemella Paramadina (2013) dan Ulfi Kartika Oktaviana (2011) yang menyatakan tidak terdapat perbedaan abnormal return sebelum dan setelah perubahan komposisi indeks. Namun hasil penelitian ini memiliki hasil yang kontradiksi dengan penelitian sebelumnya dari Honghui Chen (2003), Fayes Elayan (2000), Ken L Bechman (2004).

Hasil pengujian mengenai terdapat tidaknya abnormal return di sekitar pengumuman perubahan komposisi ISSI, terlihat bahwa terdapat Average Abnormal Return (AAR) untuk saham yang reentry ISSI. Hal ini berarti pasar bereaksi terhadap peristiwa pengumuman perubahan komposisi ISSI. Dengan kata lain, pengumuman perubahan komposisi ISSI dipersepsikan memiliki kandungan informasi oleh pelaku pasar. Pengujian ini juga menunjukkan hasil bahwa tidak terdapat perbedaan abnormal return antara sebelum dan sesudah pengumuman reentry dalam ISSI. Tidak signifikannya perbedaan abnormal return tersebut mungkin disebabkan karena telah ditemukan abnormal return sebelum tanggal pengumuman sehingga sebaran nilai abnormal return menjadi lebih luas. Hal ini bersesuaian dengan pendapat 
Brunnenmeier (2005:4) yang menyatakan bahwa pasar dikatakan tidak efisien jika terjadi kebocoran informasi. Kebocoran informasi dapat berupa isu atau informasi privat yang dibocorkan. Hal ini berimbas pada prilaku sebagian pelaku pasar yang menggunakan informasi tersebut untuk memperoleh return abnanormal return sebelum tanggal pengumuman. Namun, abnormal return yang diperoleh sebelum tanggal pengumuman membuat nilai abnormal return yang seharusnya didapatkan setelah tanggal pengumuman menurun.

\section{SIMPULAN}

Kesimpulan yang dapat diambil dari dampak pengumuman reentry terhadap perbedaan abnormal return pada perusahaan dalam ISSI di Bursa Efek Indonesia adalah hasil pengujian data menggunakan Paired Sample t-test menunjukkan bahwa tidak terdapat perbedaan abnormal return yang secara statistik sebelum dan sesudah pengumuman reentry.

Penelitian ini diharapkan dapat bermanfaat bagi investor, bagi perusahaan, dan bagi penelitian-penelitian selanjutnya. Berdasarkan simpulan yang ada, saran yang dapat diberikan oleh peneliti adalah bagi investor perlu memikirkan secara cermat dalam melakukan investasi dana kepada perusahaan yang reentry karena hasil dari penelitian masih memiliki kontradiksi dengan penelitian sebelumnya. Bagi peneliti-peneliti selanjutnya diharapkan dapat lebih menyempurnakan penelitian ini. Pada penelitian ini masih terdapat banyak kelemahan antara lain keterbatasan tahun yang digunakan dan penghitungan abnormal return. Peneliti selanjutnya diharapkan 
ISSN: 2302-8556

E-Jurnal Akuntansi Universitas Udayana

Vol.25.1.Oktober (2018): 83-108

dapat menggunakan metode perghitungan abnormal return lainnya seperti CAPM,

Mean adjusted model, atau Market adjuted model sebagai bahan pembanding.

\section{REFERENSI}

Duque, João dan Madeira, Gustavo. 2004. Effects Associated with Index Composition Changes: Evidence from Euronext Lisbon Stock Exchange. Journal of Business 351-383

Elayan, Fayez, Li Wenjie., dan Pinfold, John. 2000. Price Effect of Changes to the Composition of New Zealand Share Indices. Social Science Reasearch

Fama, E.F. 1970, Efficient Capital Markets: A Review Of Theory and Empirical Work, Journal of Finance, hal. 383-417.

Hartono, Jogiyanto. 2013. Teori Portofolio dan Analisis Investasi. Edisi Kedelapan. Yogyakarta : BPFE.

Indriantoro, N. B. Supomo, 2009. Metodologi Penelitian Bisnis. Yogyakarta: BPFEYogyakarta.

Luhur, Suryo. 2010. Reaksi Pasar Modal Indonesia Seputar Pemilihan Umum 8 Juli 2009 pada Saham LQ-45. Jurnal Keuangan dan Perbankan. 14 (2)

Oktaviana, Ulfi Kartika dan Nanik Wahyuni.2011.Pengaruh Perubahan Komposisi Jakarta Islamic Index Terhadap Return Saham. Jurnal eL-QUDWAH - Volume 1 Nomor 5, edisi April 2011.

Rahyuda, I Ketut. Murjana Yasa, I.G.W. Dan Yuliarmi, Ni Nyoman. 2004. Metodologi Penelitian. Fakultas Ekonomi Universitas Udayana, Denpasar.

Sugiyono. 2009. Metode Penelitian Bisnis. Bandung: CV Alfabeta.

Sulaiman, Wahid. 2002. Statistik Non-Parametrik, Contoh Kasus dan Pemecahannya dengan SPSS. Yogyakarta: Andi. 
Siti Roviah dan Dodik Ariyanto. Reaksi ...

Tolbert, Michelle. 2012. A Reentry Education Model. Education Publication Center Washington, D.C

Woon, Wong Shou.2014. Introduction to the Event Study Methodology. Singapore Management University 